\title{
Article
}

\section{D Printing of Meat Following Supercritical Fluid Extraction}

\author{
Abhilash Aditya ${ }^{1,2}(\mathbb{D})$ and Namsoo Peter Kim 1,2,3,*(D) \\ 1 Center for Printable Materials Certificate, The University of Texas at El Paso, EL Paso, TX 79968, USA; \\ aaditya@utep.edu \\ 2 Department of Metallurgical Materials and Biomedical Engineering, The University of Texas at El Paso, \\ EL Paso, TX 79968, USA \\ 3 Brain Pool Program, Korea University, Seoul 02841, Korea \\ * Correspondence: nkim@utep.edu; Tel.: +1-915-747-7996; Fax: +1-915-747-8036
}

\section{check for} updates

Citation: Aditya, A.; Kim, N.P. 3D Printing of Meat Following Supercritical Fluid Extraction. Foods 2022, 11, 554. https://doi.org/ $10.3390 /$ foods 11040554

Received: 11 January 2022 Accepted: 12 February 2022 Published: 15 February 2022

Publisher's Note: MDPI stays neutral with regard to jurisdictional claims in published maps and institutional affiliations.

Copyright: () 2022 by the authors. Licensee MDPI, Basel, Switzerland. This article is an open access article distributed under the terms and conditions of the Creative Commons Attribution (CC BY) license (https:// creativecommons.org/licenses/by/ $4.0 /)$.

\begin{abstract}
With the spread of COVID-19, understanding the spread of food poisoning, managing food materials related to chronic diseases, food ingredients' reliability, and non-face-to-face or untact delivery methods are rapidly emerging. A new field of meat research has been introduced for hygienic and healthy recipes to maintain freshness and control personalized ingredients using supercritical processes and 3D printing technology. Supercritical fluid extraction processes (SCF) and untact 3D printing technology will replace traditional meat freshness assessment based on color change according to the degree of oxidation of myoglobin in meat. SCF processes safely and quickly remove residual blood from meat and control fat and cholesterol that may be harmful to the human body. SCF-processed, high-viscosity meats are printed remotely through repeated IoT system variable experiments in WEB-CLOUD between UTEP in Texas, USA, and Korea University in Seoul, Korea. The SCF process in this study confirmed a weight reduction of $8.5 \%$ to $22.5 \%$, depending on the temperature, pressure, and SCF process time. Under conditions of a tip size of $1.0 \times 10^{-3} \mathrm{~m}$, a shear rate of $200 / \mathrm{s}$, and a maximum pressing force of $170 \mathrm{~N}$, a $1000 \mathrm{~cm}^{3}$ SCF-processed meat was successfully $3 \mathrm{D}$ printed at the other site by transmitting G-code through web.
\end{abstract}

Keywords: supercritical fluid (SCF); 3D-printed meat; untact food delivery

\section{Introduction}

There are many problems with the traditional assessment of the freshness of meat using the degree of oxidation by myoglobin. Myoglobin increases with muscle mass and age, and for beef, the inside turns bright red when the internal temperature is $60{ }^{\circ} \mathrm{C}$, and when red meat is cooked at 60 to $70{ }^{\circ} \mathrm{C}$, the pink darkens and becomes grayish brown. The oxidation of proteins, including myoglobin, exhibits various colors depending on heat and the degree of oxidation [1]. This study implements a method of maintaining freshness using an SCF process capable of 3D printing by removing residual blood, fat, and softening the texture. The Food and Agriculture Organization of the United States (FAO) recommends cooking meat for at least $3 \mathrm{~min}$ at an internal temperature of at least $63{ }^{\circ} \mathrm{C}$ to kill bacteria [2]. As the temperature rises, a red liquid containing myoglobin and water is extracted from the meat, making it bad for hygiene and aesthetics. There is a movement to create healthy dishes across societies where people are increasingly interested in maintaining a diet and monitoring nutrition by eating organic and hygienic foods [3-5]. Lately, the realization of personalized diet benefits via the accurate and fast printing of hygienic food demonstrates the potential of the technology in food engineering [6,7]. This study proposes a new paradigm shift in food processing, aiding significant advancements in the food industry [8-10]. This study tries to provide an SCF process and printable texture to remove bacteria at low temperatures. Apart from its religious significance, halal food is widely recognized as better quality food, attracting consumers for various reasons, from a healthy lifestyle perspective to restrictions on dairy products and other chemicals such 
as alcohol used in food preparation [11]. However, the unexpected surge in demand for halal foods and the lack of its regulations results in contamination during the delivery process [12-16]. Therefore, a technology that processes halal meat quickly, economically, and hygienically to remove certain ingredients is required. A technology that can receive significant attention from consumers with an excellent potential for processing unique food ingredients is necessary. The proposed SCF process for the safe handling of meat serves as an essential tool for food processing and refining [17]. The SCF process widely applied in the culinary industry so far is as follows. Table 1 illustrates the effective treatment methods used for the extraction of ingredients from various food materials [18-21]. The study focuses on providing a platform for scientifically applying the SCF extraction process of meat, followed by 3D printing.

Table 1. Food materials commonly treated using supercritical extraction [22,23].

\begin{tabular}{|c|c|c|}
\hline Materials & Treatment Method & Extracted Ingredients \\
\hline Vegetables & $\begin{array}{l}\text { Temperature range of } 35-65^{\circ} \mathrm{C} \text { and } \\
\text { pressure of } 4.05 \times 107 \mathrm{~Pa} \text {. Hexane or } \\
\text { chloroform as co-solvent. }\end{array}$ & $\begin{array}{l}\text { Extracted carotene from carrots, } \\
\text { sweet potatoes, paprika, and } \\
\text { tomato paste. }\end{array}$ \\
\hline $\begin{array}{l}\text { Dairy } \\
\text { products }\end{array}$ & $\begin{array}{l}\text { Temperature range of } 60-80^{\circ} \mathrm{C} \text { and } \\
\text { pressure of } 3.70 \times 107 \sim 5.47 \times 107 \mathrm{~Pa} \text {. } \\
\text { Methanol or ethanol as co-solvents. }\end{array}$ & $\begin{array}{l}\text { Extracted vitamin } \mathrm{A} \text { and } \mathrm{E} \text { from } \\
\text { cow milk and removing fat. }\end{array}$ \\
\hline $\begin{array}{l}\text { Eucalyptus } \\
\text { leaves }\end{array}$ & $\begin{array}{l}\text { A temperature of } 50{ }^{\circ} \mathrm{C} \text { and pressure of } \\
\qquad 2.03 \times 107 \mathrm{~Pa}\end{array}$ & Extracted plant oil \\
\hline Coffee beans & $\begin{array}{c}\text { A temperature of } 90^{\circ} \mathrm{C} \text { and pressure range } \\
\text { of } 1.60 \times 107 \sim 2.20 \times 107 \mathrm{~Pa} \text {. Water as } \\
\text { co-solvent. }\end{array}$ & $\begin{array}{c}\text { Decaffeination of green coffee } \\
\text { beans }\end{array}$ \\
\hline $\begin{array}{l}\text { Wine and } \\
\text { beer }\end{array}$ & $\begin{array}{l}\text { Temperature range of } 25-40^{\circ} \mathrm{C} \text { and } \\
\text { pressure range of } 7.60 \times 106 \sim 3.00 \times 107 \mathrm{~Pa} \text {. }\end{array}$ & Decreased alcohol concentration \\
\hline
\end{tabular}

Nevertheless, there is a requirement for advanced nutritional management to provide significant benefits for individuals with specific food allergies and dietary habits $[9,24]$. The convergence of the SCF process and 3D printing opens a new way to create customized hygienic food ingredients capable of precise control over nutritional composition. The SCF process enables faster residual blood extraction when juxtaposed with the traditional halal meat process. The study attempts the simultaneous extraction of cholesterol and residual blood, making the process efficient and economical. Moreover, 3D printing technology is one of the most anticipated engineering applications in the food industry.

Furthermore, SCF-processed foods possess porridge-like consistency, which is crucial as a building material in 3D printing. More specifically, the largest particle size is less than $5 \times 10^{-5} \mathrm{~m}$ in diameter, and 3D printing of customized foods is possible if the moisture content is appropriately adjusted [25-28]. Some progress towards perfecting the 3D printing of meat ha become apparent, and soon the importance and scope of such a technique will be demonstrated $[29,30]$. 3D printing of food, meat, or meat substitutes requires specific textures critical to printability, and the SCF process can provide these essential textures and printability [31,32]. It is worth noting that the benefits of personalized food ingredients post-SCF-process and Internet of Things (IoT)-integrated 3D printing technology with a piston-type extruder (PTE) for high viscous printing can help children or the elderly who have difficulty swallowing food, further contributing to long-distance printing [33-35]. The results of this study provide critical information about processing parameters such as head speed, the required pressure drop, and the relationship between linear velocity and shear rate that is essential for the 3D printing of SCF-extracted meat. 


\section{Materials and Methods}

\subsection{Meat Preparation}

Commercially available beef and chicken procured for the study underwent preexperimental analysis, which resulted in no significant change in color and mass. However, the chicken was not subjected to the extraction process before 3D printing. A total of $5.00 \pm 0.50 \mathrm{~g}$ of chicken and beef was pulverized at 6000 24,000 RPM over five minute cycles using a NINJA ${ }^{\circledR}$ meat grinder. Three pulverization cycles were necessary and essential to maintain a size no larger than $5.0 \times 10^{-5} \mathrm{~m}$, to facilitate SCF extraction and allow better passage of $\mathrm{CO}_{2}$ into the meat. The pulverized chicken and beef were refrigerated at $-20{ }^{\circ} \mathrm{C}$ in plastic bags to prevent meat degradation before experimentation.

\subsection{SCF Extraction}

SCF extraction utilizes an OCO-LAB apparatus shown in Figure 1a, where carbon dioxide $\left(\mathrm{CO}_{2}\right)$ serves as the solvent. The extraction apparatus includes a collection vessel, a sample extraction vessel, and a pressure monitor. The processed meat and the extract are collected separately to quantify the extraction yield. The apparatus includes an extraction vessel with a maximum operating pressure of $5.07 \times 10^{7} \mathrm{~Pa}$. Pressure in the extraction vessel was kept constant by monitoring the gas pressure gauge in Figure $1 c$, and an internal sensor monitored the temperature. SCF extraction was performed at an inclination of about $45^{\circ}$ to soak the sample in co-solvent and $\mathrm{CO}_{2}$ supercritical solvent. $10 \mathrm{~mL}$ of co-solvent was added by micropipette to the samples after being placed in an extraction vessel. The experimental conditions were as described in Table 2.

(a)

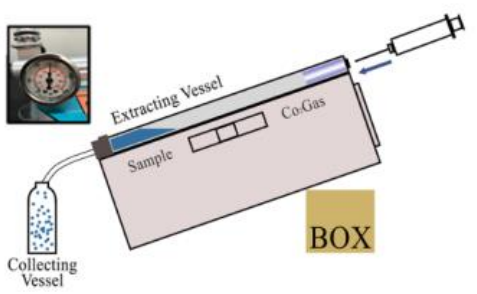

(b)

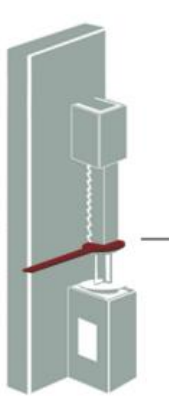

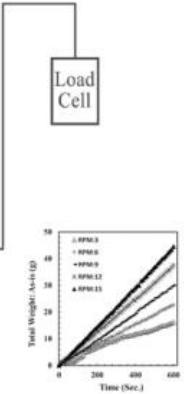

(c)

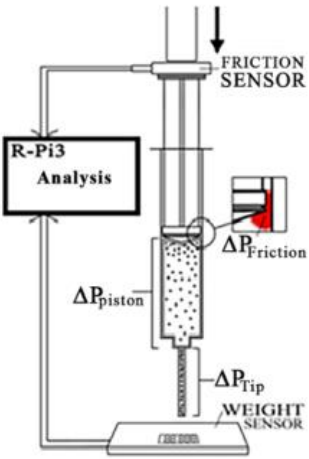

Figure 1. (a) A conceptual diagram of a supercritical extraction system, including a collection vessel a sample extraction vessel, and a pressure monitor, and images of OCO-LABS parts. (b) IoT system control system including a weight control sensor. (c) Three-pressure drop concept diagram for 3D printing quantitative distribution.

Table 2. Supercritical extraction conditions.

\begin{tabular}{cccc}
\hline SCF Time (min) & Extraction Temperature $\left({ }^{\circ} \mathbf{C}\right)$ & Pressure $\times \mathbf{1 0}^{\mathbf{7}} \mathbf{( P a )}$ & Co-Solvent \\
\hline \multirow{3}{*}{$35 \pm 5$} & 2.03 & - \\
& & 3.04 & - \\
\cline { 2 - 4 } 40 & \multirow{2}{*}{$50 \pm 5$} & 4.05 & - \\
& & 2.03 & - \\
\hline \multirow{3}{*}{$50 \pm 5$} & 3.04 & Water \\
& & 4.05 & Water \\
& & 3.04 & Vegetable oil \\
& & 4.05 & Vegetable oil \\
\hline
\end{tabular}

The extractions were conducted for $40 \mathrm{~min}$ to allow enough time for the SCF to dissolve the target components. Extractions were performed at $35 \pm 5{ }^{\circ} \mathrm{C}$ or $50 \pm 5{ }^{\circ} \mathrm{C}$, 
using vegetable oil and water as co-solvents with $\mathrm{CO}_{2}$, respectively, and at three different pressures, $2.03 \times 10^{7}, 3.04 \times 10^{7}$, and $4.05 \times 10^{7} \mathrm{~Pa}$. The experiment was conducted three times for each condition.

\subsection{D Printing of Meat}

The 3D printer utilized a piston-type extruder (PTE) with pressure sensors for precise control over the material flow, as shown in Figure 1b,c. Integration of IoT enabled remote and long-distance 3D printing. The experiments include 3D printing on-site at the University of Texas at El Paso, TX, USA, and Korea University, Seoul, Korea, demonstrating the capability of remote and long-distance $3 \mathrm{D}$ printing. The pressure required for the constant discharge of material and the pressure drop throughout the print were quantified through repeated experiments. The Raspberry Pi system installed in the printer recorded the pressure applied on the piston, the distance of the piston movement, and the weight of the material extruded in real-time. The experiments were conducted with air and water to acquire preliminary data, in order to elucidate the optimal printing process parameters for 3D printing meat. The forces caused by the friction between the components and the material accounts for the pressure drop. The friction between the piston and the inner wall of the cylinder $\left(\Delta \mathrm{P}_{\text {Friction }}\right)$, the resistance of the piston on the material $\left(\Delta \mathrm{P}_{\text {Piston }}\right)$, and the resistance offered by the nozzle tip to the extruded material $\left(\Delta \mathrm{P}_{\text {Tip }}\right)$ constitutes the pressure $\operatorname{drop}\left(\Delta \mathrm{P}_{\text {Total }}\right)$ in real-time.

As SCF extraction efficiency was increased, the extracted meat inevitably resulted in a porridge-like texture. Conversely, the meat's porridge-like texture is the most crucial factor in the quantitative control of 3D-printed foods. The clustered meat particles, solvent, and weight ratio of each were controlled to create the final printable fluid state. PTE tips ranging from $10^{-4}$ to $10^{-2} \mathrm{~m}$ allowed precise control and quantitative release for $3 \mathrm{D}$ meat printing. The 3D printer's ability to print the material wth such consistency makes it capable of printing food with similar consistencies to, and not limited to, mashed vegetables, fish (sushi), and varieties of dough. The printing parameters used for halal chicken, halal beef, and SCF-processed beef were PTE head speeds in the range of $1.0 \times 10^{-3}-1.8 \times 10^{-2} \mathrm{~m} / \mathrm{s}$, three different tip sizes, and indoor deposition temperature.

\section{Results and Discussion}

The treatment process's optimization needed three sets of experiments using a nontoxic, cost-effective, and rapid SCF process speed, producing foods like porridge under various extracting conditions. Each beef sample was extracted with a different pressure $\left(2.03 \times 10^{7} \mathrm{~Pa}, 3.04 \times 10^{7} \mathrm{~Pa}\right.$, and $\left.4.05 \times 10^{7} \mathrm{~Pa}\right)$, vessel temperature $\left(35 \pm 5^{\circ} \mathrm{C}\right.$ and $50 \pm 5^{\circ} \mathrm{C}$ ), and different co-solvents (vegetable oil and water) (Figure 2).

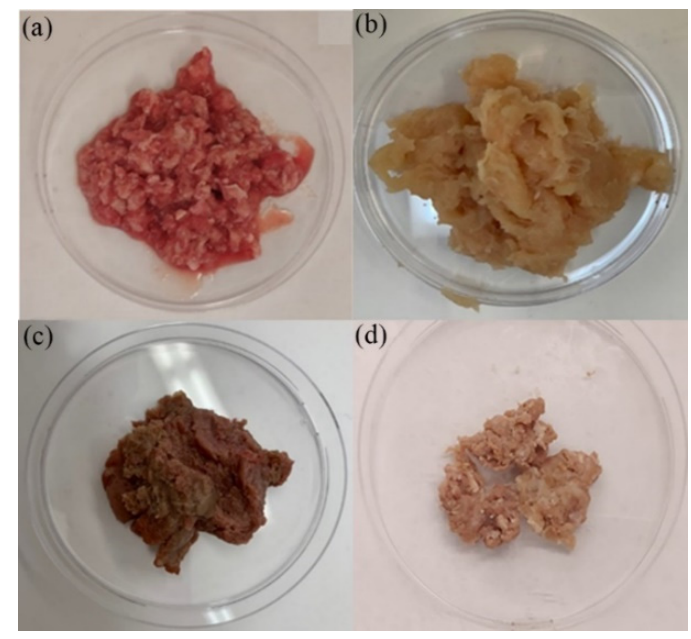

Figure 2. Samples of; (a): unprocessed beef; (b): unprocessed halal chicken; (c): unprocessed halal beef; (d): SC- $\mathrm{CO}_{2}$-processed beef under pressure at $3.04 \times 10^{7} \mathrm{~Pa}$ and a temperature of $50 \pm 5{ }^{\circ} \mathrm{C}$. 
As illustrated in the left of Figure 3, experimental results indicate considerable weight loss in SCF-processed beef. The graph shows the weight reduction after the extraction process, as a function of three different pressures and two temperatures. All SCF-extracted beef showed less mass than the original beef (total mass: $5.0 \pm 0.5 \mathrm{~g}$ ). The presence of fat, protein, cholesterol, moisture, and lipids in the original beef contributes to its mass, and the extraction of fats, cholesterol, and lipids results in a reduced mass percentage (yield). Changes in specific components are not dealt with in detail, as this research focuses on the possibility of printing the processed meat and the conditions for optimization. The extraction yield increases with an increase in temperature and pressure in the SCF extraction process. An SCF extraction temperature of around $35 \pm 5{ }^{\circ} \mathrm{C}$ indicated increased weight reduction with an increase in pressure $\left(2.03 \times 10^{7} \mathrm{~Pa}: 8.50 \pm 0.59 \%, 3.04 \times 10^{7} \mathrm{~Pa}\right.$ : $\left.10.80 \pm 3.42 \%, 4.05 \times 10^{7} \mathrm{~Pa}: 19.72 \pm 0.70 \%\right)$. The mass of all samples $\left(2.03 \times 10^{7} \mathrm{~Pa}:\right.$ $11.60 \pm 0.46 \%, 3.04 \times 10^{7} \mathrm{~Pa}: 17.50 \pm 3.17 \%$, and $4.05 \times 10^{7} \mathrm{~Pa}: 22.45 \pm 0.76 \%$ ) at the extraction temperature of around $50 \pm 5{ }^{\circ} \mathrm{C}$ decreased more efficiently than low-temperature extractions. Due to the extraction of the dissolved components in the SCF treatment, the beef samples did not deform significantly in shape, but texture deformation due to drying characteristics was evident.
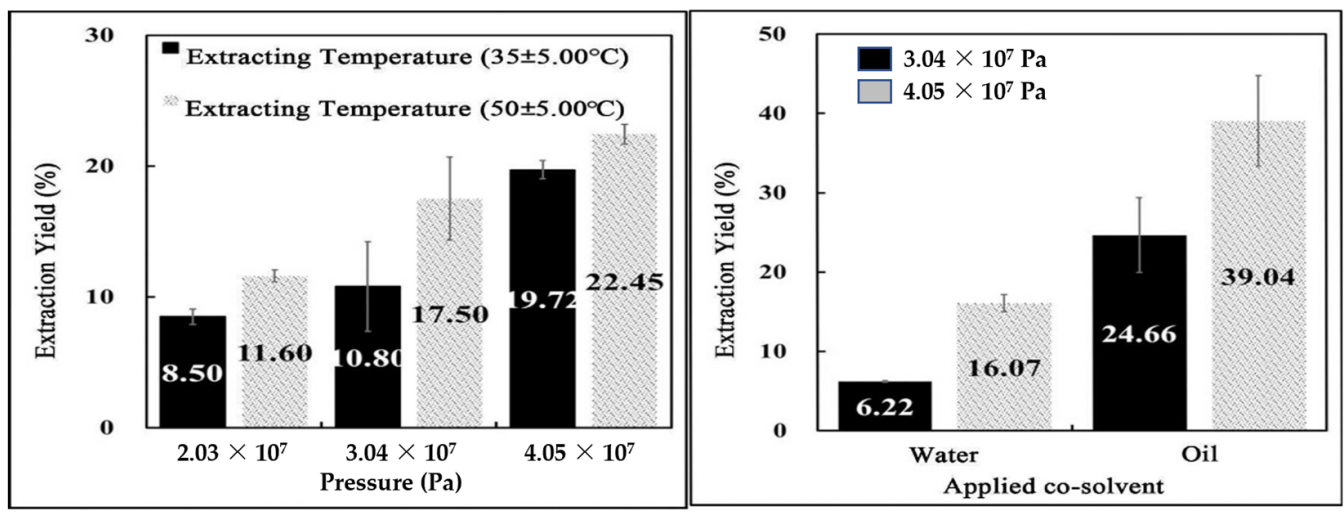

Figure 3. (Left): The effect of extracting pressure on beef fat yield rate (\%). The fat ingredient from beef samples extracted after supercritical extraction under different pressures $\left(2.03 \times 10^{7}, 3.04 \times 10^{7}\right.$, and $4.05 \times 10^{7} \mathrm{~Pa}$ ). Two different vessel temperatures were applied as $35 \pm 5{ }^{\circ} \mathrm{C}$ and $50 \pm 5{ }^{\circ} \mathrm{C}$, (Right): The effect of co-solvent liquid on beef fat yield rate (\%). The fat ingredient from beef samples extracted after supercritical extraction under the same temperature $\left(50 \pm 5^{\circ} \mathrm{C}\right)$ but different extracting pressures $\left(3.04 \times 10^{7}\right.$ and $\left.4.05 \times 10^{7} \mathrm{~Pa}\right)$ and different co-solvents (vegetable oil and water).

Visually, the beef sample's color changed to a light brown color after SCF treatment in Figure $2 \mathrm{~d}$. The extraction efficiency depends on the type of co-solvents used, and according to the observations, vegetable oil is relatively more effective in extracting lipid than water as a co-solvent (Figure 3, right). SCF with water extracted $6.22 \pm 0.10 \%$ with an extracting pressure of $3.04 \times 10^{7} \mathrm{~Pa}$, and $16.07 \pm 1.07 \%$ with an extracting pressure of $4.05 \times 10^{7} \mathrm{~Pa}$. On the other hand, SCF extraction with vegetable oil decreased mass by $24.66 \pm 4.72 \%$ at $3.04 \times 10^{7} \mathrm{~Pa}$, and $39.04 \pm 5.71 \%$ at $4.05 \times 10^{7} \mathrm{~Pa}$. Thus, SCF treatment with carbon dioxide at high pressure, temperature, and utilizing a vegetable oil co-solvent results in higher lipid and fat loss yield. The experimental results in Figure $4 \mathrm{c}$, d visually confirm lower blood diffusion in water with oil as a co-solvent. Higher pressure improved solvent extraction efficiency by increasing its density and solubility, by utilizing non-polar material as co-solvents. 


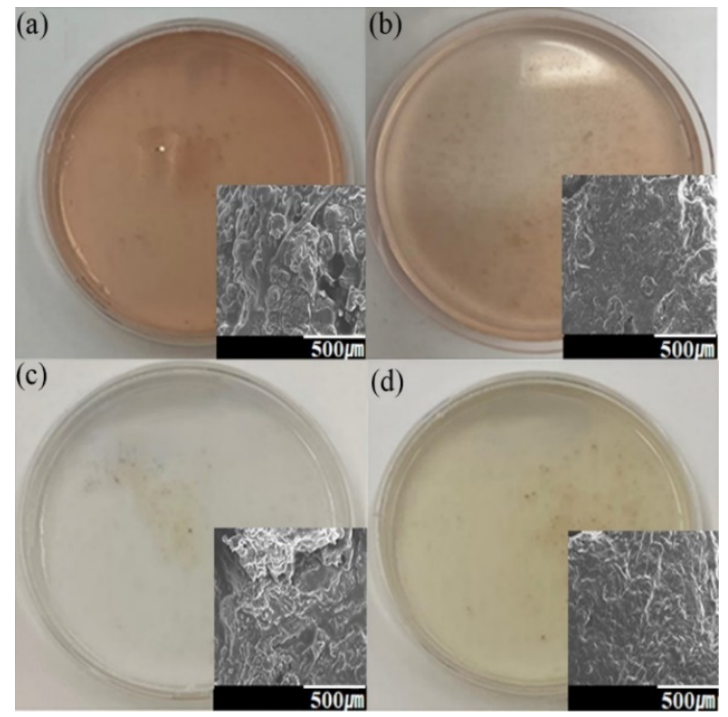

Figure 4. Images of blood diffused in water using SEM for (a): unprocessed beef; (b): unprocessed halal beef; (c): SCF under pressure at $3.04 \times 10^{7}$ Pa processed with water as a co-solvent; and (d): SCF under pressure at $3.04 \times 10^{7} \mathrm{~Pa}$ processed with oil as a co-solvent.

The Hagen-Poiseuille (HP) equation expressed below includes the following constants. $\mathrm{q}_{\mathrm{w}}=\operatorname{mass}$ flux $(\mathrm{g} / \mathrm{s}), \mathrm{r}=$ the internal radius of the piston or tip $(\mathrm{m}), \Delta \mathrm{P}=$ the pressure drop (Pa), $\rho=$ density of the materials $\left(\mathrm{g} / \mathrm{cm}^{3}\right), \mu=$ fluid viscosity $(\mathrm{Pa} \cdot \mathrm{s})$, and $\mathrm{L}=$ the length of the tip or piston $(\mathrm{m})$.

$$
\mathrm{q}_{\mathrm{w}}=\frac{\pi \mathrm{r}^{4} \Delta \mathrm{P} \rho}{8 \mu \mathrm{L}}
$$

A fundamental experiment was conducted to apply the HP to food materials containing water and air with Newtonian behavior and water with relatively high viscosity. Based on an existing experiment, the three components must be sufficiently reviewed to control PTE quantitatively, but real foods are not enough to overcome the configured total pressure drop $\left(\Delta \mathrm{P}_{\text {Total }}\right)$. The applicable water and air results are as follows in Table 3.

Table 3. Discharge data for air and water volume and pressure intensification experiment results, according to tip size and press-speed (velocity of the press).

\begin{tabular}{|c|c|c|c|c|c|c|c|c|c|c|}
\hline & $\begin{array}{l}\text { Velocity of } \\
\text { Press (m/s) }\end{array}$ & $\underset{(\mathrm{m})}{\text { Tip Size }}$ & $\begin{array}{c}\text { Shear Rate } \\
(1 / \mathrm{s})\end{array}$ & $\begin{array}{l}\Delta \mathbf{P}_{\text {Friction }} \\
(\mathbf{P a})\end{array}$ & $\begin{array}{c}\text { STDEV of } \\
\Delta P_{\text {Friction }}\end{array}$ & $\begin{array}{c}\Delta \mathbf{P}_{\mathrm{Tip}} \\
(\mathbf{P a})\end{array}$ & $\begin{array}{c}\text { STDEV of } \\
\Delta \mathbf{P}_{\text {Tip }}\end{array}$ & $\begin{array}{c}\Delta \mathbf{P}_{\text {Piston }} \\
(\mathbf{P a})\end{array}$ & $\underset{\left(\mathrm{m}^{3} / \mathrm{s}\right)}{\mathrm{q}_{\mathrm{v}}}$ & STDEV of $q_{v}$ \\
\hline \multirow{24}{*}{ Air } & $8.33 \times 10^{-5}$ & $4.00 \times 10^{-4}$ & $2.99 \times 10^{2}$ & $2.39 \times 10^{4}$ & $1.83 \times 10^{3}$ & $4.06 \times 10^{-1}$ & $2.20 \times 10^{-1}$ & $1.47 \times 10^{-5}$ & $1.50 \times 10^{-8}$ & $8.16 \times 10^{-9}$ \\
\hline & $8.33 \times 10^{-5}$ & $2.00 \times 10^{-4}$ & $2.34 \times 10^{3}$ & $2.67 \times 10^{4}$ & $2.32 \times 10^{3}$ & $6.39 \times 10^{0}$ & $2.69 \times 10^{0}$ & $1.44 \times 10^{-5}$ & $1.47 \times 10^{-8}$ & $6.22 \times 10^{-9}$ \\
\hline & $8.33 \times 10^{-5}$ & $1.10 \times 10^{-4}$ & $1.43 \times 10^{4}$ & $2.88 \times 10^{4}$ & $2.60 \times 10^{3}$ & $7.04 \times 10^{1}$ & $3.37 \times 10^{1}$ & $1.45 \times 10^{-5}$ & $1.49 \times 10^{-8}$ & $7.13 \times 10^{-9}$ \\
\hline & $8.33 \times 10^{-5}$ & $7.50 \times 10^{-5}$ & $4.49 \times 10^{4}$ & $3.04 \times 10^{4}$ & $1.41 \times 10^{3}$ & $3.25 \times 10^{2}$ & $1.49 \times 10^{2}$ & $1.45 \times 10^{-5}$ & $1.49 \times 10^{-8}$ & $6.81 \times 10^{-9}$ \\
\hline & $1.67 \times 10^{-4}$ & $7.50 \times 10^{-4}$ & $2.94 \times 10^{2}$ & $4.19 \times 10^{4}$ & None & $2.13 \times 10^{-1}$ & None & $9.47 \times 10^{-5}$ & $9.73 \times 10^{-8}$ & None \\
\hline & $3.33 \times 10^{-4}$ & $7.50 \times 10^{-4}$ & $5.81 \times 10^{2}$ & $3.62 \times 10^{4}$ & None & $4.21 \times 10^{-1}$ & None & $1.88 \times 10^{-4}$ & $1.93 \times 10^{-7}$ & None \\
\hline & $5.00 \times 10^{-4}$ & $7.50 \times 10^{-4}$ & $8.72 \times 10^{2}$ & $2.98 \times 10^{4}$ & None & $6.31 \times 10^{-1}$ & None & $2.81 \times 10^{-4}$ & $2.89 \times 10^{-7}$ & None \\
\hline & $6.67 \times 10^{-4}$ & $7.50 \times 10^{-4}$ & $1.14 \times 10^{3}$ & $1.99 \times 10^{4}$ & None & $8.26 \times 10^{-1}$ & None & $3.68 \times 10^{-4}$ & $3.78 \times 10^{-7}$ & None \\
\hline & $8.33 \times 10^{-4}$ & $1.00 \times 10^{-3}$ & $1.90 \times 10^{1}$ & $1.55 \times 10^{4}$ & $9.20 \times 10^{2}$ & $1.03 \times 10^{-2}$ & $1.03 \times 10^{-2}$ & $1.46 \times 10^{-5}$ & $1.49 \times 10^{-7}$ & $7.40 \times 10^{-9}$ \\
\hline & $8.33 \times 10^{-4}$ & $7.50 \times 10^{-4}$ & $4.52 \times 10^{1}$ & $2.07 \times 10^{4}$ & $1.41 \times 10^{3}$ & $3.27 \times 10^{-2}$ & $1.63 \times 10^{-2}$ & $1.46 \times 10^{-5}$ & $1.50 \times 10^{-7}$ & $7.44 \times 10^{-9}$ \\
\hline & $8.33 \times 10^{-4}$ & $1.00 \times 10^{-3}$ & $1.83 \times 10^{2}$ & $1.44 \times 10^{4}$ & $1.85 \times 10^{3}$ & $9.93 \times 10^{-2}$ & $7.58 \times 10^{-3}$ & $1.40 \times 10^{-4}$ & $1.44 \times 10^{-7}$ & $1.10 \times 10^{-8}$ \\
\hline & $8.33 \times 10^{-4}$ & $7.50 \times 10^{-4}$ & $4.32 \times 10^{2}$ & $2.08 \times 10^{4}$ & $1.30 \times 10^{3}$ & $3.13 \times 10^{-1}$ & $2.32 \times 10^{-2}$ & $1.40 \times 10^{-4}$ & $1.43 \times 10^{-7}$ & $1.06 \times 10^{-8}$ \\
\hline & $8.33 \times 10^{-4}$ & $7.50 \times 10^{-4}$ & $1.41 \times 10^{2}$ & $1.90 \times 10^{4}$ & None & $1.02 \times 10^{0}$ & None & $4.56 \times 10^{-4}$ & $4.68 \times 10^{-7}$ & None \\
\hline & $8.33 \times 10^{-4}$ & $4.00 \times 10^{-4}$ & $2.86 \times 10^{3}$ & $2.13 \times 10^{4}$ & $1.35 \times 10^{3}$ & $3.88 \times 10^{0}$ & $3.17 \times 10^{-1}$ & $1.40 \times 10^{-4}$ & $1.44 \times 10^{-7}$ & $1.17 \times 10^{-8}$ \\
\hline & $8.33 \times 10^{-4}$ & $2.00 \times 10^{-4}$ & $2.28 \times 10^{4}$ & $2.50 \times 10^{4}$ & $1.58 \times 10^{3}$ & $6.20 \times 10^{1}$ & $4.91 \times 10^{0}$ & $1.40 \times 10^{-4}$ & $1.44 \times 10^{-7}$ & $1.14 \times 10^{-8}$ \\
\hline & $8.33 \times 10^{-4}$ & $1.10 \times 10^{-4}$ & $1.38 \times 10^{5}$ & $2.90 \times 10^{4}$ & $1.92 \times 10^{3}$ & $6.80 \times 10^{2}$ & $6.15 \times 10^{1}$ & $1.40 \times 10^{-4}$ & $\begin{array}{l}1.44 \times 10 \\
1.44 \times 10^{-7}\end{array}$ & $1.14 \times 10 \times 10^{-8}$ \\
\hline & $1.67 \times 10^{-4}$ & $7.50 \times 10^{-4}$ & $8.58 \times 10^{2}$ & $2.96 \times 10^{4}$ & $1.28 \times 10^{3}$ & $1.00 \times 10^{0}$ & $0.00 \times 10^{0}$ & $2.77 \times 10^{-4}$ & $\begin{array}{l}1.44 \times 10 \\
284 \times 10^{-7}\end{array}$ & $992 \times 10^{-9}$ \\
\hline & $1.67 \times 10^{-3}$ & $4.00 \times 10^{-4}$ & $5.66 \times 10^{3}$ & $2.94 \times 10^{4}$ & $8.92 \times 10^{2}$ & $8.00 \times 10^{0}$ & $0.00 \times 10^{0}$ & $2.77 \times 10^{-4}$ & $2.84 \times 10^{-7}$ & $1.01 \times 10^{-8}$ \\
\hline & $1.67 \times 10^{-3}$ & $2.00 \times 10^{-4}$ & $4.51 \times 10^{4}$ & $2.61 \times 10^{4}$ & $1.40 \times 10^{3}$ & $1.23 \times 10^{2}$ & $4.00 \times 10^{0}$ & $2.76 \times 10^{-4}$ & $2.83 \times 10^{-7}$ & $8.83 \times 10^{-9}$ \\
\hline & $1.67 \times 10^{-3}$ & $1.10 \times 10^{-4}$ & $2.75 \times 10^{5}$ & $3.41 \times 10^{4}$ & $1.16 \times 10^{3}$ & $1.36 \times 10^{3}$ & $5.40 \times 10^{1}$ & $2.80 \times 10^{-4}$ & $2.87 \times 10^{-7}$ & $1.14 \times 10^{-8}$ \\
\hline & $3.33 \times 10^{-3}$ & $7.50 \times 10^{-4}$ & $1.67 \times 10^{3}$ & $3.14 \times 10^{4}$ & $5.37 \times 10^{2}$ & $1.21 \times 10^{0}$ & $2.76 \times 10^{-2}$ & $5.40 \times 10^{-4}$ & $5.55 \times 10^{-7}$ & $1.26 \times 10^{-8}$ \\
\hline & $3.33 \times 10^{-3}$ & $4.00 \times 10^{-4}$ & $1.10 \times 10^{4}$ & $3.47 \times 10^{4}$ & $9.43 \times 10^{2}$ & $1.49 \times 10^{1}$ & $4.43 \times 10^{-1}$ & $5.38 \times 10^{-4}$ & $5.53 \times 10^{-7}$ & $1.64 \times 10^{-8}$ \\
\hline & $3.33 \times 10^{-3}$ & $2.00 \times 10^{-4}$ & $8.83 \times 10^{4}$ & $3.31 \times 10^{4}$ & $5.14 \times 10^{2}$ & $2.40 \times 10^{2}$ & $5.68 \times 10^{0}$ & $5.40 \times 10^{-4}$ & $5.55 \times 10^{-7}$ & $1.31 \times 10^{-8}$ \\
\hline & $3.33 \times 10^{-3}$ & $1.10 \times 10^{-4}$ & $5.33 \times 10^{5}$ & $4.49 \times 10^{4}$ & $8.73 \times 10^{3}$ & $2.63 \times 10^{3}$ & $4.58 \times 10^{1}$ & $5.42 \times 10^{-4}$ & $5.57 \times 10^{-7}$ & $9.70 \times 10^{-9}$ \\
\hline
\end{tabular}


Table 3. Cont.

\begin{tabular}{|c|c|c|c|c|c|c|c|c|c|c|}
\hline & $\begin{array}{l}\text { Velocity of } \\
\text { Press (m/s) }\end{array}$ & $\underset{\text { (m) }}{\text { Tip Size }}$ & $\begin{array}{c}\text { Shear Rate } \\
(1 / \mathrm{s})\end{array}$ & $\begin{array}{l}\Delta \mathbf{P}_{\text {Friction }} \\
(\mathbf{P a})\end{array}$ & $\begin{array}{c}\text { STDEV of } \\
\Delta \mathbf{P}_{\text {Friction }}\end{array}$ & $\underset{(\mathbf{P a})}{\Delta \mathbf{P}_{\mathrm{Tip}}}$ & $\begin{array}{c}\text { STDEV of } \\
\Delta \mathbf{P}_{\text {Tip }}\end{array}$ & $\begin{array}{c}\Delta \mathbf{P}_{\text {Piston }} \\
(\mathbf{P a})\end{array}$ & $\underset{\left(\mathrm{m}^{3} / \mathrm{s}\right)}{\mathrm{q}_{\mathrm{v}}}$ & STDEV of $q_{v}$ \\
\hline \multirow{16}{*}{ Water } & $8.33 \times 10^{-5}$ & $2.00 \times 10^{-4}$ & $2.37 \times 10^{3}$ & $4.83 \times 10^{3}$ & $3.10 \times 10^{2}$ & $3.17 \times 10^{2}$ & $1.06 \times 10^{1}$ & $6.41 \times 10^{-4}$ & $1.49 \times 10^{-8}$ & $4.99 \times 10^{-10}$ \\
\hline & $8.33 \times 10^{-5}$ & $4.00 \times 10^{-4}$ & $2.95 \times 10^{2}$ & $5.76 \times 10^{3}$ & $1.01 \times 10^{3}$ & $1.91 \times 10^{1}$ & $3.23 \times 10^{0}$ & $6.36 \times 10^{-4}$ & $1.48 \times 10^{-8}$ & $2.18 \times 10^{-10}$ \\
\hline & $8.33 \times 10^{-5}$ & $7.50 \times 10^{-4}$ & $4.56 \times 10^{1}$ & $4.89 \times 10^{3}$ & $4.15 \times 10^{2}$ & $1.62 \times 10^{0}$ & $1.15 \times 10^{-1}$ & $6.49 \times 10^{-4}$ & $1.51 \times 10^{-8}$ & $1.07 \times 10^{-9}$ \\
\hline & $8.33 \times 10^{-5}$ & $1.00 \times 10^{-3}$ & $1.92 \times 10^{1}$ & $6.08 \times 10^{3}$ & $4.06 \times 10^{2}$ & $5.13 \times 10^{-1}$ & $5.13 \times 10^{-1}$ & $6.49 \times 10^{-4}$ & $1.51 \times 10^{-8}$ & $1.05 \times 10^{-9}$ \\
\hline & $8.33 \times 10^{-4}$ & $2.00 \times 10^{-4}$ & $2.17 \times 10^{4}$ & $1.09 \times 10^{3}$ & $9.20 \times 10^{2}$ & $2.89 \times 10^{3}$ & $1.74 \times 10^{2}$ & $6.52 \times 10^{-4}$ & $1.37 \times 10^{-7}$ & $8.19 \times 10^{-9}$ \\
\hline & $8.33 \times 10^{-4}$ & $4.00 \times 10^{-4}$ & $2.72 \times 10^{3}$ & $8.19 \times 10^{3}$ & $1.64 \times 10^{3}$ & $1.76 \times 10^{2}$ & $3.13 \times 10^{1}$ & $6.54 \times 10^{-3}$ & $1.36 \times 10^{-7}$ & $7.63 \times 10^{-9}$ \\
\hline & $8.33 \times 10^{-4}$ & $7.50 \times 10^{-4}$ & $4.13 \times 10^{2}$ & $8.73 \times 10^{3}$ & $8.04 \times 10^{2}$ & $1.47 \times 10^{1}$ & $7.41 \times 10^{-1}$ & $6.55 \times 10^{-3}$ & $1.37 \times 10^{-7}$ & $6.90 \times 10^{-9}$ \\
\hline & $8.33 \times 10^{-4}$ & $1.00 \times 10^{-3}$ & $1.74 \times 10^{2}$ & $8.45 \times 10^{3}$ & $9.85 \times 10^{2}$ & $4.64 \times 10^{0}$ & $4.64 \times 10^{0}$ & $6.53 \times 10^{-3}$ & $1.36 \times 10^{-7}$ & $7.83 \times 10^{-9}$ \\
\hline & $1.67 \times 10^{-3}$ & $2.00 \times 10^{-4}$ & $4.29 \times 10^{4}$ & $2.86 \times 10^{4}$ & $3.16 \times 10^{3}$ & $5.71 \times 10^{3}$ & $5.18 \times 10^{2}$ & $1.29 \times 10^{-2}$ & $2.70 \times 10^{-7}$ & $2.44 \times 10^{-8}$ \\
\hline & $1.67 \times 10^{-3}$ & $4.00 \times 10^{-4}$ & $5.37 \times 10^{3}$ & $1.16 \times 10^{4}$ & $2.43 \times 10^{3}$ & $3.46 \times 10^{2}$ & $7.30 \times 10^{1}$ & $1.29 \times 10^{-2}$ & $2.70 \times 10^{-7}$ & $2.14 \times 10^{-8}$ \\
\hline & $1.67 \times 10^{-3}$ & $7.50 \times 10^{-4}$ & $8.17 \times 10^{2}$ & $1.10 \times 10^{4}$ & $8.31 \times 10^{2}$ & $2.91 \times 10^{1}$ & $2.18 \times 10^{0}$ & $1.30 \times 10^{-2}$ & $2.71 \times 10^{-7}$ & $2.03 \times 10^{-8}$ \\
\hline & $1.67 \times 10^{-3}$ & $1.00 \times 10^{-3}$ & $3.45 \times 10^{2}$ & $1.04 \times 10^{4}$ & $1.14 \times 10^{3}$ & $9.22 \times 10^{0}$ & $9.22 \times 10^{0}$ & $1.30 \times 10^{-2}$ & $2.71 \times 10^{-7}$ & $1.92 \times 10^{-8}$ \\
\hline & $3.33 \times 10^{-3}$ & $2.00 \times 10^{-4}$ & $8.59 \times 10^{4}$ & $5.76 \times 10^{4}$ & $4.54 \times 10^{3}$ & $1.14 \times 10^{4}$ & $9.89 \times 10^{2}$ & $2.57 \times 10^{-2}$ & $5.40 \times 10^{-7}$ & $4.65 \times 10^{-8}$ \\
\hline & $3.33 \times 10^{-3}$ & $4.00 \times 10^{-4}$ & $1.07 \times 10^{4}$ & $2.10 \times 10^{4}$ & $2.93 \times 10^{3}$ & $7.12 \times 10^{2}$ & $6.38 \times 10^{1}$ & $2.57 \times 10^{-2}$ & $5.37 \times 10^{-7}$ & $4.80 \times 10^{-8}$ \\
\hline & $3.33 \times 10^{-3}$ & $7.50 \times 10^{-4}$ & $1.63 \times 10^{3}$ & $1.62 \times 10^{4}$ & $1.84 \times 10^{3}$ & $5.79 \times 10^{1}$ & $4.71 \times 10^{0}$ & $2.58 \times 10^{-2}$ & $5.38 \times 10^{-7}$ & $4.38 \times 10^{-8}$ \\
\hline & $3.33 \times 10^{-3}$ & $1.00 \times 10^{-3}$ & $6.83 \times 10^{2}$ & $1.69 \times 10^{4}$ & $2.21 \times 10^{3}$ & $1.82 \times 10^{1}$ & $1.82 \times 10^{1}$ & $2.57 \times 10^{-2}$ & $5.36 \times 10^{-7}$ & $4.64 \times 10^{-8}$ \\
\hline
\end{tabular}

The fundamental experiment involves the printing process, but with just an empty cylinder. The data acquired from the experiment generates primary quantitative spill data for extruding air, which helps understand $\Delta \mathrm{P}_{\text {Friction }}$ as an essential variable. Understanding the pressure drop due to friction is crucial, as the applied force must exceed $\Delta \mathrm{P}_{\text {Friction }}$ for accurate control of the pressure to print different materials. However, $\Delta \mathrm{P}_{\text {Friction }}$ in the experiment is $2.88 \times 10^{7} \mathrm{~Pa}$ at the smallest tip size available, and is a few hundred times larger than the other two pressure drops $\left(\Delta \mathrm{P}_{\text {Piston }}\right.$ and $\left.\Delta \mathrm{P}_{\text {Tip }}\right)$. Figure 5 provides empirical data for the part that depended on the HP equation to show the degree of change in the piston's friction and resistance values, with tip size proving the cylinder is pressurized enough to print with the smallest tip size.
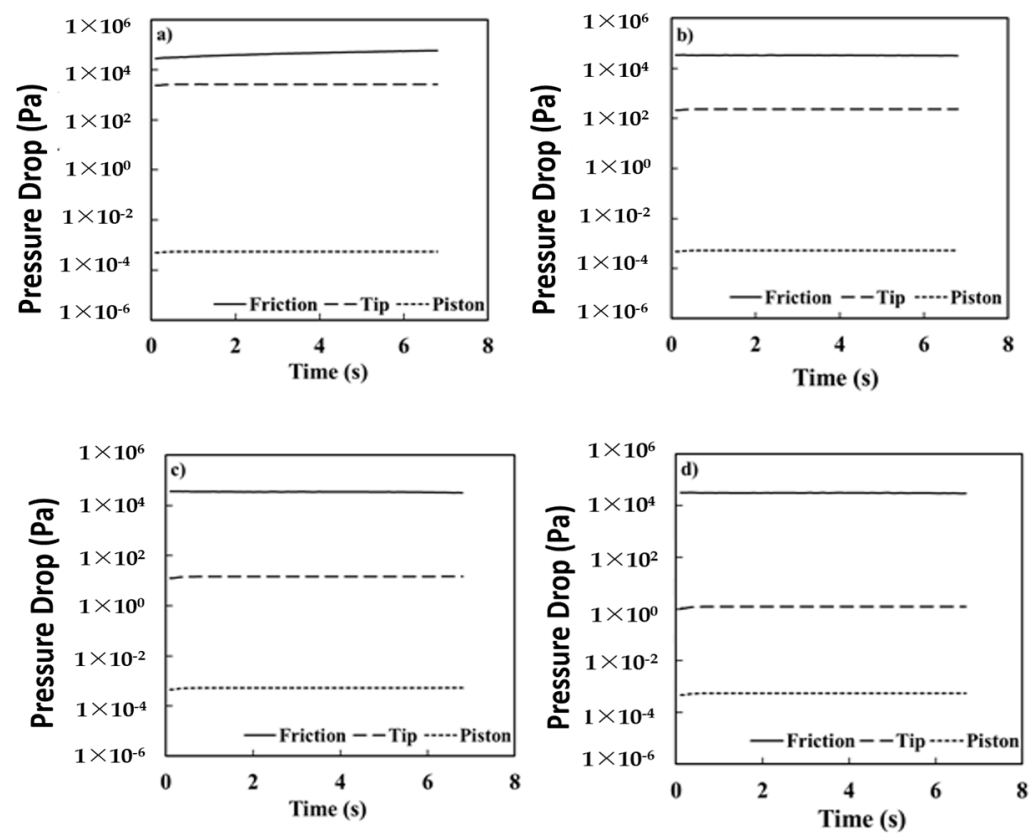

Figure 5. The pressure drop for friction, piston, and tip, for air piston head press at $3.3 \times 10^{-3} \mathrm{~m} / \mathrm{s}$ with various tip sizes; (a) $1.1 \times 10^{-4} \mathrm{~m}$; (b) $2.0 \times 10^{-4} \mathrm{~m}$; (c) $4.0 \times 10^{-4} \mathrm{~m}$; (d) $7.5 \times 10^{-4} \mathrm{~m}$.

On the other hand, a similar fundamental experiment with water instead of air, with tip sizes $2.0 \times 10^{-4}, 4.0 \times 10^{-4}, 7.5 \times 10^{-4}$, and $1.0 \times 10^{-3} \mathrm{~m}$, resulted in pressure build-up due to $\Delta \mathrm{P}_{\mathrm{Tip}}$, as water is more viscous than air (Figure 6). Hence, a tip size of $2.0 \times 10^{-4}$ offers precise control for printing as the pressure drop between the tip and the material is significant and cannot be neglected. The observations implied that $\Delta \mathrm{P}_{\text {Tip }}$ is inversely proportional to the 4 th power of the radius of the tip $\left(\mathrm{r}_{\text {Tip }}\right) . \Delta \mathrm{P}_{\text {Friction }}$ increases 
slightly with the increase in tip size, but $\Delta \mathrm{P}_{\text {Tip }}$ increases rapidly. Hence, the pressure drop between the material and the tip is not negligible. Repetitive experimentations with meat having viscosities several hundred times than that of water proved challenging to discharge quantitatively, irrespective of the meat particles' size through the largest tip size of $1.0 \times 10^{-3} \mathrm{~m}$.

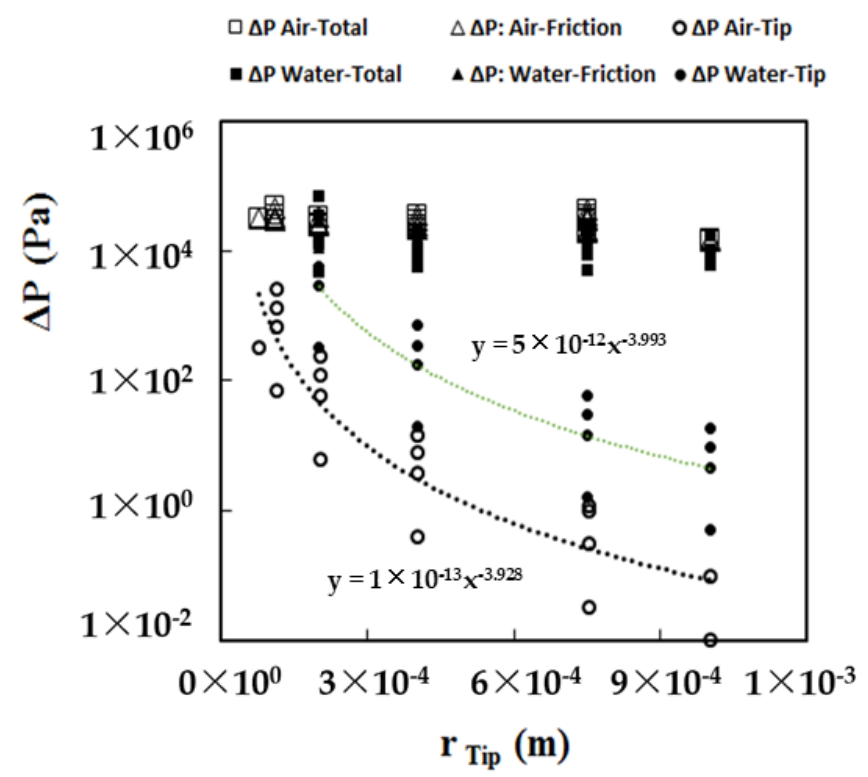

Figure 6. The pressure drop for friction, piston, and tip, for air and water with various tip sizes.

These experimentations were necessary to understand the quantitative discharge using water, as it is relatable to compare it with foods with high moisture content. The amount of water discharged constantly increases accordingly with the increase in the shear rate applied to the piston. Theoretically, the air and water are separate, but practically, such conditions are unattainable. The air and solid or air and liquid, a high-viscosity substance, behave as a whole. Unlike air, the resistance offered to the material by the tip is significantly affected due to the frictional force between the piston head and the inner wall of the piston. Therefore, the shear rate applied to the piston head increases as the measurement of the high-viscous material flow's linear velocity is shown in Figure 7. Experimentally, it is expected that meat printing is possible if ingredients such as meat are crushed to a certain level and devoid of lumps. When discharging material containing water and air, the print head speed should be $0.1 \mathrm{~m} / \mathrm{s}$ and the shear rate should be stable below $1000 / \mathrm{s}$. Since the slurry type meat has a viscosity of several hundred times more, at a shear rate of 1000/s, higher pressure is expected to be applied for stable discharge.

The texture of the SCF-treated meat increases the possibility of printing through a 3D printer. The consistency of the SCF meat's grain size enables the continuous discharge required for stable printing, while minimizing clogging problems. Repeat experiments were performed for two-dimensional high-viscosity printing, obtained by applying a head speed of $1.8 \times 10^{-2} \mathrm{~m} / \mathrm{s}$ and tip size of $1.1 \times 10^{-3} \mathrm{~m}$ (Figure 8 ). Optimal conditions for the printing process of the single-line design (SLD) were verified [33]. The gridline design consisting of straight lines has proven to be a useful structure for optimizing 3D-printed food products' thickness and emissions. When the head speed is in the range of $1.0 \times 10^{-3}$ to $1.8 \times 10^{-2} \mathrm{~m} / \mathrm{s}$, consistent discharge is evident throughout the printing process. The total time required is \pm 1.0 to $1.5 \mathrm{~s}$. A speed of $1.8 \times 10^{-2} \mathrm{~m} / \mathrm{s}$ turned out to be the most stable head speed. 


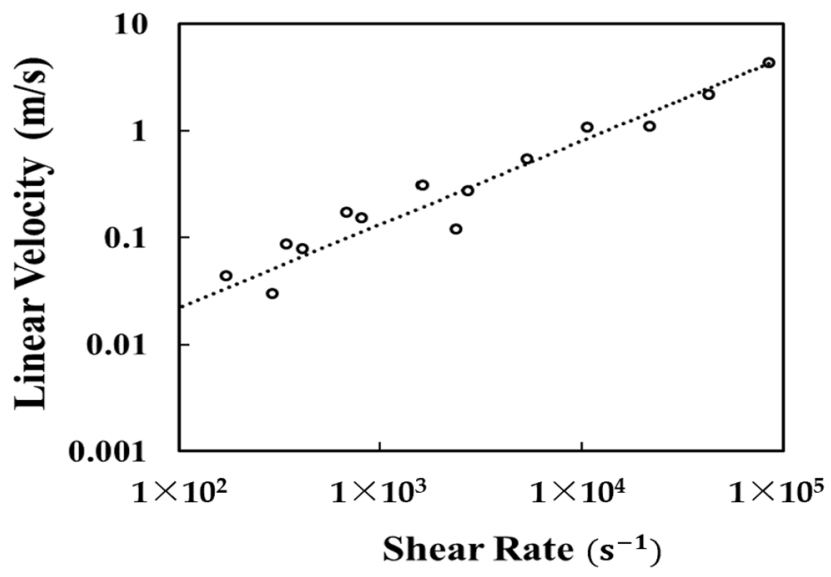

Figure 7. The linear velocity of water vs. various shear rates of PTE.

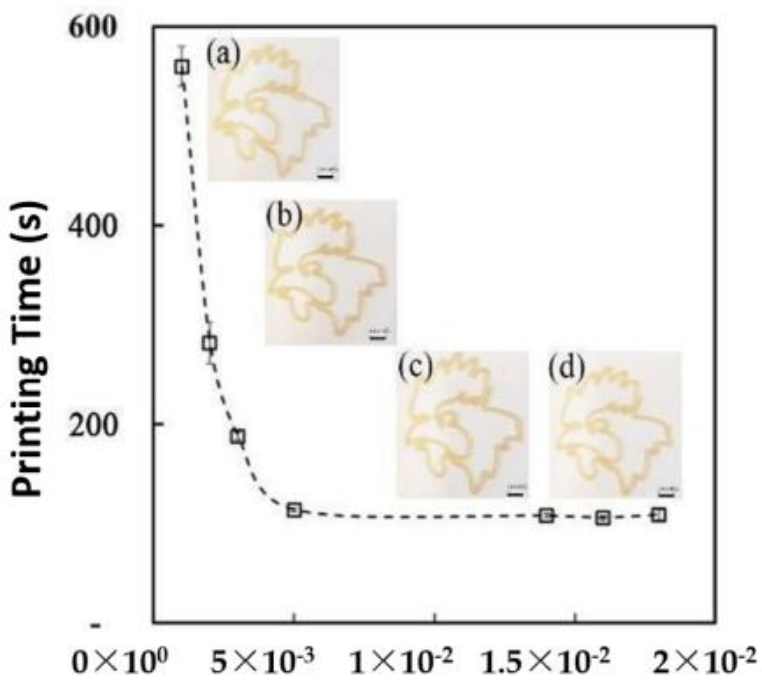

(a)

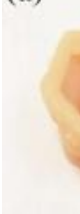

(b)

(c)

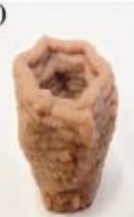

d)

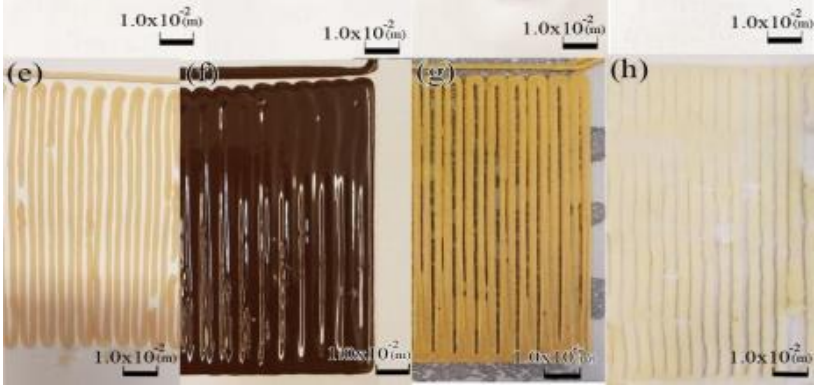

Head Traveling Speed $(\mathrm{m} / \mathrm{s})$

Figure 8. (Left): The accuracy of $2.5 \mathrm{D}$ printed images as printing time reduces with the increase in head traveling speed. (a) Head traveling speed: $1.0 \times 10^{-3} \mathrm{~m} / \mathrm{s}$; (b): head traveling speed: $5.0 \times 10^{-3} \mathrm{~m} / \mathrm{s}$; $(\mathbf{c})$ : head traveling speed: $1.5 \times 10^{-2} \mathrm{~m} / \mathrm{s}$; and $(\mathbf{d})$ : head traveling speed: $1.8 \times 10^{-2} \mathrm{~m} / \mathrm{s}$. (Right): Images of 2.5D and 3D printed food. (a): 3D-printed vase design with Halal chicken (head speed $1.8 \times 10^{-2} \mathrm{~m} / \mathrm{s}$ and tip size $1.0 \times 10^{-3} \mathrm{~m}$ ); (b): 3D-printed Chun-Sung-Dae design with Halal chicken (head speed $7.0 \times 10^{-3} \mathrm{~m} / \mathrm{s}$ and tip size $3.2 \times 10^{-4} \mathrm{~m}$ ); (c): 3D-printed vase design with SCF beef sample (head speed $1.8 \times 10^{-2} \mathrm{~m} / \mathrm{s}$ and tip size $1.0 \times 10^{-3} \mathrm{~m}$ ); (d): 3D-printed vase design with Halal beef (head speed 1. $8 \times 10^{-2} \mathrm{~m} / \mathrm{s}$ and tip size $\left.7.5 \times 10^{-4} \mathrm{~m}\right)$; (e): $2.5 \mathrm{D}$ printed grid line with SCF-processed beef (head speed $1.8 \times 10^{-2} \mathrm{~m} / \mathrm{s}$ and tip size $1.0 \times 10^{-3} \mathrm{~m}$ ); (f): $2.5 \mathrm{D}$-printed grid line with chocolate (head speed $1.8 \times 10^{-2} \mathrm{~m} / \mathrm{s}$ and tip size $1.0 \times 10^{-3} \mathrm{~m}$ ); (g): $2.5 \mathrm{D}$-printed grid line with peanut butter (head speed $1.8 \times 10^{-2} \mathrm{~m} / \mathrm{s}$ and tip size $1.0 \times 10^{-3} \mathrm{~m}$ ); and (h): $2.5 \mathrm{D}$-printed grid line with potato (head speed $1.8 \times 10^{-2} \mathrm{~m} / \mathrm{s}$ and tip size $1.0 \times 10^{-3} \mathrm{~m}$ ).

Adopting the Internet of Things (IoT) controlled non-face-to-face and real-time 3D printing systems, we combined multiple distinct patterns simultaneously in the Raspberry Pie controller and Arduino microprocessor with different inks accurately controlled in size and positioning. The inclusion of a web-based 3D printing process enabled data transfer from the University of Texas at El Paso to print food in a facility in Korea University, thereby successfully demonstrating long-distance printing. In Figure 8 (right, a), the 3D printing process using Halal chicken breast with a tip size of $1.0 \times 10^{-3} \mathrm{~m}$ was implemented, and uniformly discharged $2.14 \mathrm{~g}$ for $720 \mathrm{~s}$. As shown in Figure 8 (right, b), the 3D design 
"Chum-Sung-Dae (ancient astronomical observatory)" was delicately printed, and only discharged $0.42 \mathrm{~g}$ for $1200 \mathrm{~s}$. A reduced tip size of $3.2 \times 10^{-4} \mathrm{~m}$ ensures printing of a more complicated and delicate sized 3D structures. In addition to the significant increase in printability and accuracy for Halal chicken by decreased tip size, head speed reduced from $1.8 \times 10^{-2} \mathrm{~m} / \mathrm{s}$ to $7.0 \times 10^{-3} \mathrm{~m} / \mathrm{s}$. The printability of foods for the initial $1200 \mathrm{~s}$ with a constant force and flow rate was confirmed. The material released at a tip size of $3.2 \times 10^{-4} \mathrm{~m}$ stacked to a thickness of $4.0 \times 10^{-4} \mathrm{~m}$, and the results indicated that layer formation was successful due to the nature of the high-viscosity material of meat sticking to consecutive layers. As shown in Figure 8 (right, c,d), 3D printing with SCF and Halal beef material was also performed. Furthermore, the use of tip size $1.0 \times 10^{-3} \mathrm{~m}$ verified the printability by discharging $3.03 \mathrm{~g}$ for $600 \mathrm{~s}$. The smaller tip $\left(7.5 \times 10^{-4} \mathrm{~m}\right)$ was used, and derived the vase's delicate shape by continuously discharging $2.67 \mathrm{~g}$ for $600 \mathrm{~s}$. Moreover, $3 \mathrm{D}$ printing experiments with SC- $\mathrm{CO}_{2}$ processed beef and other food materials (chocolate, peanut butter, and ground potato) were successful. As seen in the gridline structure of Figure 8 (right, e-h), the 3D printing process was successfully implemented for $160 \mathrm{~s}$.

\section{Conclusions}

The SCF process quickly processes meat to a printable state, further removing fats and cholesterol that could be harmful to the human body, and producing hygienic and customizable ingredients. Printing of halal beef and regular chicken, along with SCFprocessed beef, was successful. SCF meat created 3D printable structures with advanced custom materials such as slurry and gel-type texture control. In the SCF process's meat treatment, the high temperature and extraction pressure increased the process efficiency by $22.5 \%$, and the use of a co-solvent confirmed the effect of reducing meat weight by up to $39.4 \%$. Due to the inherent polarity of the co-solvent, water was effective in extracting residual blood or myoglobin. It has proven to be much more effective in removing fat from meat using co-solvents. These SCFs and the 3D printing process are essential when developing personalized foods that allow fine-tuned nutritional control to meet specific dietary requirements. Printing parameters are optimized for high-viscosity PTE 3D printing of halal meat ingredients and SCF-processed beef. It has identified interest in the food industry and new cooking methodologies, and new possibilities for 3D-printed meat production. In this study, 3D meat printing was successfully attempted in real-time, including long-distance printing over two continents via the web in a non-face-to-face or untact manner.

Author Contributions: Conceptualization, N.P.K. and A.A.; methodology, N.P.K.; software, A.A.; validation, N.P.K. and A.A.; formal analysis, A.A.; investigation, A.A.; resources, N.P.K.; data curation, A.A.; writing — original draft preparation, A.A. and N.P.K.; writing—review and editing, A.A.; visualization, A.A.; supervision, N.P.K.; project administration, N.P.K.; funding acquisition, N.P.K. All authors have read and agreed to the published version of the manuscript.

Funding: This study was supported by the Korean Research Foundation's Brain Pool Fellowship Program, Development of a non-face-to-face telemedicine system (2020H1D3A2A02085514), and equipment from Perkin Elmer.

Institutional Review Board Statement: Not applicable.

Informed Consent Statement: Not applicable.

Data Availability Statement: Data is contained within the article.

Conflicts of Interest: The authors declare no conflict of interest.

\section{References}

1. Hunt, M.; Sorheim, O.; Slinde, E. Color and Heat Denaturation of Myoglobin Forms in Ground Beef. J. Food Sci. 1999, 64, 847-851. [CrossRef]

2. FAO. Food Handlers Manual Instructor. 2017. Available online: http://www.fao.org/3/a-i5896e.pdf (accessed on 1 March 2021). 
3. Ab Talib, M.S.; Sawari, S.S.M.; Hamid, A.B.A.; Chin, T.A. Emerging Halal food market: An Institutional Theory of Halal certificate implementation. Manag. Res. Rev. 2016, 39, 987-997. [CrossRef]

4. Mumuni, A.G.; Veeck, A.; Luqmani, M.; Quraeshi, Z.A.; Kamarulzaman, Y. Religious identity, community and religious minorities search efforts for religiously sanctioned food: The case of halal food in non-Muslim majority markets. Int. J. Consum. Stud. 2018, 42, 586-598. [CrossRef]

5. Aziz, Y.A.; Chok, N.V. The Role of Halal Awareness, Halal Certification, and Marketing Components in Determining Halal Purchase Intention Among Non-Muslims in Malaysia: A Structural Equation Modeling Approach. J. Int. Food Agribus. Mark. 2013, 25, 1-23. [CrossRef]

6. Yang, F.; Zhang, M.; Bhandari, B. Recent development in 3D food printing. Crit. Rev. Food Sci. Nutr. 2017, 57, 3145-3153. [CrossRef]

7. Kim, N.; Eo, J.; Cepeda, B.; Kim, J. A New Paradigm of Pharmaceutical Drug Delivery Systems (DDS): Challenges for Space, Time, and Shapes. Innov. Pharm. 2018, 9, 11. [CrossRef]

8. Adamek, J. Halal food market vs. Polish meat producers. On the dissimilarities in approaching the idea of sustainable development. Pr. Nauk. Uniw. Ekon. We Wrocławiu 2015, 397, 9-19. [CrossRef]

9. Riaz, M.N.; Chaudry, M.M. Halal Food Production; CRC Press: Boca Raton, FL, USA, 2003.

10. Zailani, S.; Arrifin, Z.; Wahid, N.A.; Othman, R.; Fernando, Y. Halal Traceability and Halal Tracking Systems in Strengthening Halal Food Supply Chain for Food Industry in Malaysia (A Review). J. Food Technol. 2010, 8, 74-81. [CrossRef]

11. Nakyinsige, K.; Fatimah, A.B.; Aghwan, Z.A.; Zulkifli, I.; Goh, Y.M.; Sazili, A.Q. Bleeding Efficiency and Meat Oxidative Stability and Microbiological Quality of New Zealand White Rabbits Subjected to Halal Slaughter without Stunning and Gas Stun-killing. Asian-Australas. J. Anim. Sci. 2014, 27, 406-413. [CrossRef]

12. Alvarado, C.; McKee, S. Marination to Improve Functional Properties and Safety of Poultry Meat. J. Appl. Poult. Res. 2007, 16, 113-120. [CrossRef]

13. Leal-Ramos, M.Y.; Alarcon-Rojo, A.D.; Mason, T.J.; Paniwnyk, L.; Alarjah, M. Ultrasound-enhanced mass transfer in Halal compared with non-Halal chicken. J. Sci. Food Agric. 2011, 91, 130-133. [CrossRef] [PubMed]

14. Sărăcin, V.C. The Halal Food Law in Malaysia. Contemp. Read. Law Soc. Justice 2017, 9, 372-382.

15. Ismail, A.G.; Ali, M.; Noor, M. Halal Finance and Halal Foods: Are They Falling Apart ? Economica 2016, 12, 113-126.

16. Johan, E. New challenges in asean regional market: International trade framework on halal standard. J. Din. Huk. 2018, 18, 93-102. [CrossRef]

17. Baiano, A. Recovery of Biomolecules from Food Wastes-A Review. Molecules 2014, 19, 14821-14842. [CrossRef]

18. Ashraf-Khorassani, M.; Gidanian, S.; Yamini, Y. Effect of Pressure, Temperature, Modifier, Modifier Concentration, and Sample Matrix on the Supercritical Fluid Extraction Efficiency of Different Phenolic Compounds. J. Chromatogr. Sci. 1995, 33, 658-662. [CrossRef]

19. Ali-Nehari, A.; Kim, S.-B.; Lee, Y.-B.; Chun, B.-S. Digestive enzymes characterization of krill (Euphausia superba) residues deoiled by supercritical carbon dioxide and organic solvents. J. Ind. Eng. Chem. 2012, 18, 1314-1319. [CrossRef]

20. Chung, S.; Kwon, H.; Kim, N.P. Supercritical extraction of decellularized extracellular matrix from porcine adipose tissue as regeneration therapeutics. J. Cosmet. Med. 2019, 3, 86-93. [CrossRef]

21. Roy, B.C.; Goto, M.; Hirose, T. Extraction of Ginger Oil with Supercritical Carbon Dioxide: Experiments and Modeling. Ind. Eng. Chem. Res. 1996, 35, 607-612. [CrossRef]

22. Raventós, M.; Duarte, S.; Alarcón, R. Application and Possibilities of Supercritical CO2 Extraction in Food Processing Industry: An Overview. Food Sci. Technol. Int. 2002, 8, 269-284. [CrossRef]

23. Wehling, R.L.; Froning, G.W.; Cuppett, S.L.; Niemann, L. Extraction of cholesterol and other lipids from dehydrated beef using supercritical carbon dioxide. J. Agric. Food Chem. 1992, 40, 1204-1207. [CrossRef]

24. Taylor-Black, S.; Wang, J. The prevalence and characteristics of food allergy in urban minority children. Ann. Allergy Asthma Immunol. 2012, 109, 431-437. [CrossRef]

25. Liu, Z.; Zhang, M.; Bhandari, B.; Yang, C. Impact of rheological properties of mashed potatoes on 3D printing. J. Food Eng. 2018, 220, 76-82. [CrossRef]

26. Kim, N.S.; Han, K.N.; Church, K.H. Direct Writing Technology for 21st Century Industries-Focus on Micro-Dispensing Deposition Write Technology. J. KSMTE 2007, 5, 511-515.

27. Kim, N.P.; Cho, D.; Zielewski, M. Optimization of 3D printing parameters of Screw Type Extrusion (STE) for ceramics using the Taguchi method. Ceram. Int. 2019, 45, 2351-2360. [CrossRef]

28. Le Tohic, C.; O'Sullivan, J.; Drapala, K.P.; Chartrin, V.; Chan, T.; Morrison, A.; Kerry, J.P.; Kelly, A.L. Effect of 3D printing on the structure and textural properties of processed cheese. J. Food Eng. 2018, 220, 56-64. [CrossRef]

29. Dick, A.; Bhandari, B.; Prakash, S. 3D printing of meat. Meat Sci. 2019, 153, 35-44. [CrossRef]

30. Değerli, C. Processed Meat Production in 3 Dimensional (3D) Printing Technology. Turk. J. Agric.-Food Sci. Technol. 2020, 8 , 1018-1026.

31. Portanguen, S.; Tournayre, P.; Sicard, J.; Astruc, T.; Mirade, P.-S. Toward the design of functional foods and biobased products by 3D printing: A review. Trends Food Sci. Technol. 2019, 86, 188-198. [CrossRef]

32. Godoi, F.C.; Prakash, S.; Bhandari, B.R. 3d printing technologies applied for food design: Status and prospects. J. Food Eng. 2016, 179, 44-54. [CrossRef] 
33. Kim, N.P.; Eo, J.-S.; Cho, D. Optimization of piston type extrusion (PTE) techniques for 3D printed food. J. Food Eng. 2018, 235, 41-49. [CrossRef]

34. Hoffman, J.; Hwang, S.; Ortega, A.; Kim, N.P.; Moon, K.-S. The Standardization of Printable Materials and Direct Writing Systems. J. Electron. Packag. 2013, 135, 011006. [CrossRef]

35. Hong, S.; Kim, N. Synthesis of 3D Printable Cu-Ag Core-Shell Materials: Kinetics of CuO Film Removal. J. Electron. Mater. 2015, 44, 823-830. [CrossRef] 